\title{
The memory of a friend: Lorenzo Capussotti (1947-2014)
}

\author{
Gennaro Nuzzo
}

Published online: 22 August 2014

(C) Springer-Verlag Italia 2014

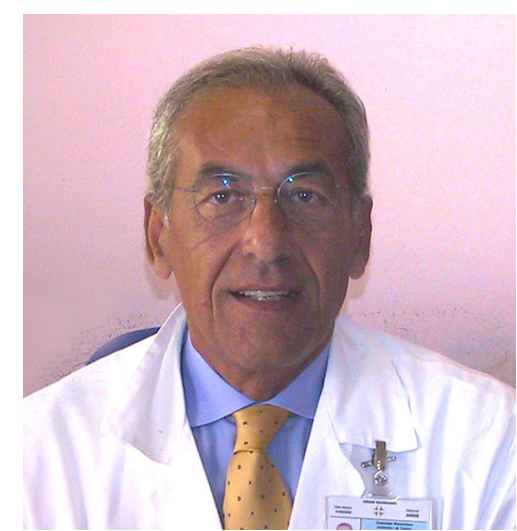

I will never forget the morning of Wednesday 18th of June when I received news of the death of Renzo. I remember those moments, at first of disbelief and pain and then a huge sense of emptiness: how will I cope without my friend and our interminable chats?

In fact Renzo had a quality that characterized him above all else, and that was to listen: he loved the art of conversation and he loved talking about everything because he was an enthusiast and a curious man.

His favorite topic of conversation was surgery, which, after Livia, Alessandro, and Umberto was his big love. After a life lived in the operating room, he was still able to get passionate about technical aspects of a particular operation or to sustain hours of discussion about a complication during surgery.

G. Nuzzo $(\bowtie)$

A. Gemelli Hospital, Catholic University of the Sacred Heart School of Medicine, Rome, Italy

e-mail: gennaro.nuzzo@rm.unicatt.it; gennanuzzo@gmail.com
It was his curiosity together with his generosity that made him available to all colleagues that needed his advice. He was always ready to listen and share his knowledge and he always did it with respect. He loved debates of clinical cases because he understood how important it was to know the patient well. He loved debates at congresses if these were based on clinical experience and on scientific data. He would become strict and could lose his temper with "amateurs" especially if presumptuous. He considered hepatic surgery something too serious, to witness stupidities in silence. But he also had no hesitation to intervene even with famous colleagues, Italian or foreign, especially if he saw the mistreatment of someone younger. Sometimes I would insist he ignored the issue, but in the end, I admired him for his character.

Surgery completely absorbed him and he dedicated the small amount of remaining time to Livia, his life companion, discreet and always close, and to Alessandro and Umberto for whom he felt a huge sense of tenderness and love that he could not hide, and they were always at the center of his thoughts.

His collaborators were like a second family to him, not only his alumni that he always protected, but also all the people who worked with him and he knew how to involve and make them feel important in their roles. In more recent times, they represented one of his major thoughts.

We loved each other and were rarely in disaccord. When this happened, I would always say that perhaps we were good friends only because more than $600 \mathrm{~km}$ were separating us. He would remind me that it was thanks to him that I had become a Hepatobiliary surgeon which was true.

I met Renzo in 1974 in Turin while I was doing my specialization in thoracic surgery; he was already a chatterbox, he listened, he was curious and through these many encounters we shared the common passion for 
Hepatobiliary surgery and for France. Renzo was the first that talked to me about a young surgeon called Henri Bismuth that later became our Maestro. It was then that we started our relationship with the French School, that Renzo believed was fundamental to his formation.

When on a sunny day in the green hills of Asti, we accompanied Renzo to the cemetery, we had together with us Dominique, Francois, and Daniel, testimonies of the love of so many foreign friends who were unable to attend.

With Renzo, it was possible to speak about everything. One can really say he loved life. He was fond of his house on the hills of Turin that he loved immediately, and he decided to take it with a courageous decision typical of his character. He loved being around his friends that he gave so much attention to. He loved the sea and even more so the one of Elba Island. He loved to travel and, after France, Argentina had taken a special place in his heart. He loved football, but it was best to ignore the topic of Juventus's league titles. He loved beautiful cars and the roar of his Maserati even though he said he only got it to please
Alessandro. He loved good food and restaurants with stars, but I remember him happy one night in a small "trattoria" on a tiny uphill road from Riviera di Chiaia in Naples. He loved good wines, but being Piedmontese, he was slightly biased. He loved art and the roman antique dealers and stories of the popular and antique Rome. How many times we agreed on going on a real roman holiday and how many more things we were supposed to do together!

When Renzo told me of the new prestigious position that he was offered, I was so happy for him. This was what he needed to overcome a difficult time. In one of our last telephone conversations, I recommended that he did not overtire himself, but I knew it was useless.

The conclusion of his life was the last sign of a desperate love for surgery, stronger than any thought for himself.

Only those who are forgotten, really die. But we, dear Renzo, will never forget you.

Conflict of interest None. 